\title{
The ICC: A Global Court to Fight Impunity or a Court Targeting Africans
}

\author{
James E. Archibong* \\ Department of Jurisprudence and International Law,Faculty of Law, University of Calabar, Nigeria \\ *Corresponding Author:James E. Archibong, Department of Jurisprudence and International Law, \\ Faculty of Law, University of Calabar, Nigeria
}

\begin{abstract}
The adoption of the Rome Statute of the International Criminal Court (ICC) marked a turning point in the quest for accountability for victims of horrendous international crimes. Since the commencement inception of trial in 2002, only persons from Africa have been arraigned despite copious evidence of similar crimes in other parts of the world. This has incurred the wrath of African leaders, alleging unfairness, neocolonialism and bias. Ordinary Africans, the victims of gross human rights violations, however, applaud the trials given the unfair, manipulative and unworkable nature of national justice system in Africa. The question therefore arises as to whether the ICC is biased against Africans. There is no doubt that the ICC has focused on Africa, ignoring heinous crimes prevalent in non-African countries. While its efforts at ending impunity and enthroning accountability in Africa is commendable, the ICC should also turn its search light on other parts of the world. This is the only way the Court can justify its creation, assume the status of custodian and dispenser of international criminal justice and divest itself of the paraphernalia of neocolonialism bestowed on it by African leaders.
\end{abstract}

Keywords:International Criminal Court, Justice, Africa, Double Standards, Neo-Colonialism

\section{INTRODUCTION}

One of the remarkable achievements of contemporary international criminal law is the development of the concept of individual criminal responsibility (Werle, 2007). Prior to the end of the Second World War, there was no international legal or institutional framework to sustain criminal charges. Individuals alleged to have committed serious international crimes were charged before national courts. The creation of the International Military Tribunals for Nuremberg and the Far East provided a reprieve and platform for the prosecution of individuals responsible for heinous crimes in the Second World War (Sands and Klein, 2004). This was followed by ad hoc tribunals for the former Yugoslavia, Rwanda, Cambodia and Sierra Leone, among others

Africa has for decades been plagued by conflicts and gross human rights abuses perpetrated in diverse conflicts such as wars of national liberation, ethnic conflicts, resistance to oppressive and murderous regimes and many others (Bangamwabo, 2008:105). The African human rights system has been described as weak and its enforcement mechanism yet to be fully operational(Bangamwabo, 2008:105). The African Court of Human Rights which was inaugurated in 1998 has been merged with the African Court of Justice to form a single judicial system called the African Court of Justice and Human Rights (which has not yet entered into force).

Victimsof international crimes rely on the national justice system which in most instances, are not impartial when international crimes are involved (Bangamwabo, 2008:105). They tend to adjudicate in favour of the ruling parties, state armed forces or government officials, and are usually biased against the opposition. Some states, especially those emerging from prolonged conflicts lack the basic infrastructure and qualified personnel to dispense justice that meet minimum standards. Thus national courts in Africa are grossly handicapped and often unwilling or unable to try international crimes.

The International Criminal Court (ICC) was created to serve as a court of last resortits primary mission being to try perpetrators of monstrous crimes when states are unwilling or unable to do so (Zavis and Dixon, 2016). This makes the Court quite suitable to deal with gross violations of human rights and international humanitarian law globally. However, since the ICC formally commenced 
operation on 1 July, 2002 till date, only persons fromAfrica have been indicted and arraigned before the Court (Zavis and Dixon, 2016). Information on grave international crimes perpetrated in nonAfrican countries such as Iraq, Venezuela, Palestine, Colombia, Syria, Yemen and Afghanistan had been presented to the ICC. The Court placed them under preliminary examination and has not decided on opening an investigation.

Palestine officially joined the ICC and is now a member (BBC, 2015). According to their Foreign Minister, Palestinians were seeking "justice not vengeance" (BBC, 2015). The government of Palestine has referred matters to the Court, but it has not conducted investigations and no formal charges have been initiated despite the heinous crimes perpetrated in the territory. This has ignited a global debate leaving many to ponder whether Africa is on trial or the ICC is biased against Africans (Alleblas et al, 2017) or is unfairly targeting Africa. The debate as to whether the ICC is targeting Africa has taken a centre stagein global discourse and will continue in the years to come.

\section{AFRICAN SUPPORT FOR THE ESTABLISHMENT OF THE ICC}

The Statute of the ICC was adopted in 1998and became functional on 1 July 2002. It is a court meant to complement national courts when trials cannot take place (Rome Statute, Article 17).According to Assogbavi (2017) the Court currently has 124 members drawn from Africa (34), Asia and the Pacific (19), Eastern Europe (18), Latin America and the Caribbean (28), and others, including Western Europe (25). While major powers like Canada, Australia, Japan and all members of the European Union embraced the Court, the US, Russia, China, India and Israel withheld their support (Groenleer, 2015).

The Court received strong support from African countries.Nantulya (2017) has observed that African states propelled the creation of the Court and made significant contribution to debates and decisions that heralded the Court. Leaders from Africa gave huge support to the ICC when it was founded, partly due to the horrible experiences of the Rwanda genocide (Zavis and Dixon, 2016). In terms of membership, Africa has the largest regional bloc of State parties (Pless, 2010). Out of 54 countries in Africa, 34 ratified the Statute and became State parties. Senegal was the first country in the world to ratify the Rome Statute (Pless, 2010).

Its premier role was widely commended in a continent plagued by armed conflict, terror, violence and gross human rights violations. The genocide in Rwanda in 1994 was the breaking point in impunity in Africa, and provided the impetus for African participation in the global criminal court. Pless (2010:6) submits that the ICC was partly created by Africans for the benefit of thousands of victims of serious crimes on the continent: "African states contributed extensively to the preparations leading up to, during and after the diplomatic conference in Rome at which the Rome Statute of the ICC was finalised." There were numerous preparatory activities and consultations across Africa in the run up to the Rome diplomatic conference. The Council of Ministers of the Organisation of African Unity (OAU), predecessor to the Africa Union (AU), adopted a resolution enjoining all their members to back the establishment of Court at its meeting of 27 February, 1998. This position was affirmed in June, 1998 by the OAU summit of Heads of State and Government (Pless, 2010:7). The adoption of the AU Constitutive Act signalled a new era in the fight to end impunity and violence in Africa. Thus a synergy between the two institutions would promote human rights, security, peace and accountability in the continent.When the Court commenced sitting in 2002, some African countries, namely Democratic Republic of. Congo (DRC), Uganda,and Central African Republic (CAR)referred certain individuals for trial.

In consideration of the considerable role Africa played in launching it, the Court has accorded a primal place and due recognition to Africans, giving a strong voice and effective representation to the continent. The cordial relationship and cooperation between the ICC and Africa also translated into key appointments for Africans (Pless, 2010). Currently, the President of the Court, Chile Eboe-Osuji and its Chief Prosecutor, Fatou Bensouda, are Africans from Nigeria and the Gambia respectively.

\section{THE ICC IS LAUNCHED WITH CASES FROM AFRICA}

The Rome Statute prescribes the jurisdiction of the Court and stipulates the procedures for commencing actions against offenders. The Prosecutor can initiate an investigation if the situation is referred by a state party or by the UN Security Council. It can also launch an investigation proprio motu based on information from individuals and organizations (Article 13). Four States Parties have 
referred situations to the Court. These are Democratic Republic of the Congo (DRC), Uganda, the Central African Republic (CAR), and Mali. The UN Security Council referred the situations in Darfur, Sudan and Libya - both non-States Parties.The Prosecutor initiated investigations proprio motu in respect of the situations in Kenya and Cote d'Ivoire.Other states under ICC preliminary examination are Honduras, South Korea, the Comoros, Colombia, Georgia, Guinea and Nigeria. The preliminary examinations so far carried out have not produced any formal charges in respect of these countries.

Numerousindividuals have been investigated and indicted by the Court, among themhigh profile personalities, serving and former heads of state, all of them from Africa.The indictment and warrant of arrest for Omar al-Bashir, at the time president of Sudancaused outrage among African leaders. While the AU intervened and unsuccessfully tried to defer that case, the Court indicted and commenced the prosecution proprio motu of Kenyan president and his deputy, and two other individuals for post-election crimes in that country. This action attracted the wrath of political and opinion leaders in Africa thereby provoking a debate as to whether the continent will pull out of the ICC (BBC, 2013). The other highly placed African personalities who were arraigned at the ICC include Laurent Gbagbo former president of Cote d'Ivoire and Jean-Pierre Bemba former Vice President of D.R. Congo. At the end of the trial, Laurent Gbagbo and an accomplice, Charles Ble Goude, were found not guilty and acquitted (BBC,2013). Jean Pierre Bemba was initially convicted and sentenced to 18 years in prison. The conviction was later overturned on appeal.

\section{FROM COMMENDATION TO CONDEMNATION}

Since the commencement of trial in 2002, it has been observed that of the 11 situations investigated or under investigation, 10 involve African countries;all the indictments and warrants of arrest so far are for Africans; and only cases involving Africans have been brought before the court for trial (Allo, 2018).Warcrimes and crimes against humanity have been committed in other parts of the world, but individuals so far indicted and prosecuted by the ICC are from Africa.Twoof those indicted weresitting heads of state.

In 2009, the ICC ordered the arrest of Omar al-Bashir, then president of Sudan, on charges of war crimes and crimes against humanity. This did not go down well with certain interests, especially the political class in Africa (Pless, 2010). The argument that he was an incumbent president did not impress either the Court or the UN Security Council. Attempts to defer the case equally failed. The ICC also indicted the Kenyan President, Uhuru Kenyatta and his Vice William Ruto in 2011 on charges of sponsoring ethnic violence after thedisputed presidential elections of 2007. In the ensuing chaos and confrontations, more than 1000 Kenyans were killed and about 500,000 displaced (Alleblas et al, 2017). The third head of state, Laurent Gbagbo, was deposed by international forces and handed over to the ICC after a keenly contested presidential election in Cote d'Ivoire.

From its formative stage, the ICC had drawn its greatest support from Africa ( Nantulya, 2017). However, only individuals from Africa have been indicted and prosecuted by the Court. Till date not a single case from any other continent of the world has been successfully investigated and brought before the Court for trial. This culminated in changing perceptions and diminishing support for the ICC in Africa. African leaders did not take kindly to the new posture of the ICC, a hitherto friendly organization which they helped to contrive and nurture.In the light of this, enraged political and opinion leaders in the continent became its arch critic (Pless, 2010). Support for the ICC among African leaders declined significantly since the indictment of some top politicians (Zavis and Dixon, 2016). The leaders frowned at the ICC alleging among othersthat:

- The Court is a hegemonic tool of western powers;

- It is a Western Court targeting African leaders;

- Itis an institution which is unfairly targeting or discriminating against Africa;

- The Court is bias;

- Its actions amount to double standards and selective justice;

- Itsfocus only on Africa is undermining African efforts to solve its problems; and interfering with efforts to achieve peace and conflict resolution processes in Africa. 


\section{IS THE ICC UNFAIRLY TARGETING AFRICANS?}

The crucial question often asked is whether the ICC is targeting Africa inappropriately. The answer is neither here nor there. However, the question has triggered public debates, and from which two schools of thought have emerged. One school is led by African political leaders, the ruling class, and their dominant perception is that the Court is an instrument of neocolonialism. The second school is dominated by ordinary Africans, civil society groups and victims of oppression and human rights abuses. They urge African states to retain their membership of the ICC and strengthen the relationship in the interest of the people, those that Kofi Annan referred to as 'the little guys.' Thus the issue of unfairness or otherwise of the ICC to Africa should be addressed from two perspectives - the perceived interests of African leaders and the welfare of the African people.

\section{PERCEPTION OF THE ICC By AfRican POLITICAL LEADERS}

It is worthy of note that since its actualization 17 years ago, every singlesituation under investigation or prosecution are from Africa. On account of this, critics argue that ICC's focus on Africa has been unfair. President Paul Kigame of Rwanda derided the Court as having been created to prosecute Africans and other poor countries, and depicted it as a new pattern of imperialism designed to constrict individuals from poverty-stricken African countries and other feeble states (Pless, 2010:20). The ICC lacks any plausible explanations as to why it received information on Iraq, Venezuela, Palestine, Colombia and Afghanistan but failed to open investigations on them. The prosecutor has yet to open investigations into crimes committed by nationals of states that are wealthy and powerful.And failure to do so has weakened its support in African countries as well as spurred the impression that the institution is biased.

The Court had been branded "White Man's Court" by political leaders in Africa (CBS News, 2009). When President Omar Bashir visited Kenya in 2010, it caused an outrage. Kenyan government officials, including the Prime Minister, claimed ignorance of Bashir's visit, maintaining that it was organized in secrecy, and they were not consulted about it. The Prime Minister described it as wrong. The matter was debated in Parliament, criticized and condemned. When however, some prominent Kenyans, including the President, Uhuru Kenyatta, and his Vice, William Ruto, were indicted by the ICC, it caused an uproar within and outside the country. After the Kenyan indictment, the ICC was described as "imperialist," "neo-colonialist" and "white man's court." The Court was said to be targeting Africa, and that Africa was on trial. Kenya declared its intention to withdraw its membership of the ICC. The Parliament of that country voted to end Kenya's membership and cooperation with the Court. To many Kenyans, the ICC was interfering in their affairs.

It is not in doubt that the ICC has exhibited an unusual interest in matters concerning Africa. In March 2015, just before the general election in Nigeria, the ICC issued a severe warning to the political gladiators that the elections should be devoid of violence (Adedimeji, 2015). The statement issued by the Court cautioned admonished that "Any person who incites or engages in acts of violence in the context of the upcoming elections or otherwise - including by ordering, inciting, encouraging or contributing to the commission of crimes that fall within ICC's jurisdiction - is liable to prosecution, either by Nigerian courts or by the ICC" (Adedimeji, 2015).

It is not clear what effect this admonition had on the conduct or outcome of the general elections. What is clear, however, is that there was no major incident of violence capable of disturbing public peace and order, and the politicians conducted themselves with some measure of decorum. For the first time in Nigeria, a sitting president lost an election, accepted defeat and congratulated the opposition candidate that won. The ICC's warning was taken seriously by the major actors. Already in pursuit of powerful individuals in Africa, nobody in Nigeria wanted to be a guest of the Court.

\subsection{Selective Justice and Double Standards}

The ICC has been accused of selective justice and double standards in its handling of cases (Kimani, 2009). There seems to be some merits in the argument put forward by some African leaders that the ICC is targeting Africans. They have raised the issue of war crimes and crimes against humanity in conflicts in other parts of the world and the suspicion that the ICC has turned blind eye to them (CBS News, 2009).The United States forces in Iraq and Afghanistan have committed war crimes which deserve to be investigated and prosecuted (Higgs, 2004). The ICC is just opening a preliminary examination into allegations of war crimes by US personnel in Afghanistan. Israel is known to have 
committed war crimes in the Palestinian territories, but the ICC remains unresponsive. Amid the reticence, the violence continues unabated (Holmes, 2018).

There have been instances of serious violations of human rights and international humanitarian law in numerous armed conflicts since 2002 when the ICC prosecutions began. Areas of conflict deserving ICC attention include Colombia, which has been embroiled in a 50-year insurgency; Georgia which fought a brief war against Russia; and eastern Ukraine where Russia is alleged to be fighting a proxy war against Ukrainian forces. But mostirksome are the ongoing conflicts in Syria, Yemen and Iraq in which civilians have been deliberately and systematically attacked, maimed, killed and raped. All sides to the conflicts have gravely violated human rights and international humanitarian law, including the use of chemical and other banned weapons in Syria (BBC, 2019). However, referral of the situations in those countries has not received the blessing of the Security Council (Alamuddin, 2012). The Council refused to refer Syria notwithstanding the similarity of circumstances to those Darfur, Sudan and Libya (Moss, 2012). The failure of the Security Council to refer other situations is "often because the state concerned has veto-wielding allies among the P-5 Council members" (Moss, 2012:11). It should be reiterated that Russia and China have vetoed any bid to invoke the jurisdiction of the ICC against Syria (Moss, 2012:11).

\subsection{A Stooge and Political Tool in the Hand of Powerful States}

The impression created in the minds of African leaders is that the ICC is simply a stooge; an agent of neocolonialism and a tool of geopolitics in the hands of powerful states. The assertion is predicated on the referral of Libya to the ICC by the United Nations Security Council (Res. 1970). The UN action was to "send a strong signal to Gaddafi and other governments in the region" (Human Rights Watch, 2011). The former Libyan head of state who had been in power for 42 years was notorious for gross human rights violations, while the western countries turned a blind eye. It is widely believed that Mummar Gaddafi; his son Saif al-Islam, Gaddafi and his intelligence chief, Abdullah Al-Senussi, were referred to the ICC for political motives. Crimes against humanity and persecution of civilians had been perpetrated in Libya long before the Arab Spring uprising. The turmoil in 2011 only provided the pretext and basis for disenchanted western powers to chase Gaddafi, dismantle his power structure, and bring him to justice before the ICC. These countries which had always accused him of sponsoring terrorism found a golden opportunity to silence him permanently. Violence and conflict occasioned by the Arab Spring occurred in Egypt, Syria and some other Arab countries, but they have been shielded from accountability by their powerful allies.

Another point of interest is the insistence of the ICC to try, Saif Al - Islam Gaddafi, without regard to the claim by the Libyan Government of its ability, willingness and readiness to try him. This negates its function as a Court of last resort whose jurisdiction is only invoked when a national justice system fails. The insistence on prosecuting Saif Al - Islam Gaddafi heightened the suspicion that the ICC was a tool in the hands of powerful states - out for revenge not justice. It was very clear that the western powers behind Libya's referral wanted regime change and the ICC became a handy tool to actualize that dream as well as a veritable option to neutralize a stubborn enemy.

The ICC's handling of the case of Laurent Gbagbo the former Ivorian president was not different. The manner of his arrest by international forces and hasty transfer to the ICC created the impression that the process was influenced by external powers that had already adjudged him apersona non grata for refusing to accept the result of the presidential election (Ba, 2016). Waging war to evict Gbagbo from the presidential mansion was not enough, his confinement in the cells of the ICC will teach him and other recalcitrant African leaders a bitter lesson (Ba, 2016). Otherwise how would the anti Gbagbo coalition explain the sidelining of Ivorian national justice system which is vested with primary jurisdiction to try offenders? Gbagbo's wife, Simone and other collaborators were tried by Ivorian courts and punished appropriately, an indicator that national courts had the capacity to conduct fair trials. In the case of Laurent Gbagbo, the ICC served as a court of first resort, driving home the suspicion that it acted under external pressure, wherever it came from.

Powerful countries in the UN Security Council use their vetoes to thwart any referral of their allies to the Court. Russia and China vetoed any attempt to refer Syria to the ICC. The US threatens to exercise its veto to prevent referral of its troops or those of its allies. As observed by James Goldston, a former staff of the ICC, "The fundamental problem is that the court is operating in a world that is 
unequal politically and economically"(Zavis and Dixon). The ICC is seen as the tool to achieve the interests of the most powerful states at the expense of weaker ones in the international system.

The failure or unwillingness of the ICC to move against perpetrators of international crimes in other parts of the world is curious. Yet it is an international court and a global dispenser of justice. If it is truly a global Court established to fight impunity, then it should be able to stand up to violations anywhere in the world no matter who is involved. But that is not the case; while the court is ready and willing to respond to violations in Africa, it ignores those of other regions and continents (Aljazeera, 2019). Even where cases are referred by a State party, the Prosecutor is not obliged to open an investigation. Palestine became a Party to the Rome Statute in 2015 and has referred mattersrelating to crimes committed on its territory to the Court(Holmes, 2018). The ICC has declined to open an investigation apparently for fear of the US and Israel (Bob, 2019). Against this backdrop, Murphy (2013) opines that "many of the criticisms (against the Court) are valid."

\section{THE ICC THROUGH THE LENSES OF ORDINARY AFRICANS}

\subsection{Ordinary Africans Support the ICC}

The allegations leveled against the ICC are weighty. Quite often analysts wonder whether they are valid, baseless or untenable. This has also broadened the debate as to how ordinary Africans, often victims of oppression, dictatorship and tyranny, see the ICC.There are indeed dissenting voices from Africa, an indicator that strong criticisms and vocal opposition by African leaders do not in any way represent the point of view or stance of ordinary Africans on the ICC. Majority of them would want perpetrators of war crimes and crimes against humanity to be accountable before a court of justice.It has been observed that the ICC enjoys strong public support in Africa notwithstanding the squabble it is embroiled in. Kimani (2009) remarks that "More than 130 civil society and human rights groups from 30 African countries have called on their governments to rethink their opposition to the Bashir indictment." Roth (2014) also affirms that "the ICC gains support from human rights groups and many ordinary citizens because of its promise of justice for the victims of mass atrocities."

The visit of President Bashir to Kenya in 2010 caused outrage and incurred strong condemnation from Kenyan civil society, media and the general public (VOA Africa, 2010). Africa civil society groups in more than 30 countries have highlighted the importance and relevance of the ICC to Africa; and equally canvassed for collaboration and support for the institution. When Omar al-Bashir visited Nigeria in 2013, there was an outrage and condemnation by members of the public. A coalition of non-governmental organizations approached a Federal High Court to get the Nigerian government to enforce the ICC warrant for the arrest of al Bashir (Besant, 2013). In addition, there were peaceful protests by several groups and individuals at the venue of the AU Summit denouncing the Nigerian government. In June, 2015former president Omar al-Bashir visited South Africa to attend an AU Summit and was briefly detained on the orders of a court and at the instance of civil society groups (BBC, 2015). The South African authorities surreptitiously "smuggled" him out of the country as the court considered his arrest (Bowcott, 2015).

The decision not to arrest Omar al Bashir did not enjoy unanimity among African leaders. The government of Botswana rejected the idea of reneging on its responsibility to the Court (Keppler, 2011:5). In South Africa, the African National Congress declared an unalloyed backing for the ICC and urged cooperation to enable the Court achieve its mandate (Keppler, 2011:5).

\subsection{African Public Support for the ICC: A Case Study of Nigeria}

The ICC has also been inundated with different kinds of complaints from Nigerians, who are seeking but cannot obtain justice and redress in Nigerian courts. Nigerians have demonstrated unwavering faith and confidence in the ability of the ICC to hold their leaders accountable and dispense justice to thousands of the downtrodden, oppressed and forgotten Nigerians. This has been expressed in the number of petitions sent to the Court, which traverse a number of critical issues such as insecurity, corruption and human rights violations. The petitions have emanated from individuals, political parties and civil society groups (Punch, 2018).

Agitators for the state of Biafra from the south eastern part of the country have had to contend with onslaughts by the armed forces, resulting in gross human rights violations. Both local and international human rights activists have petitioned the ICC over the intensification of violence 
against Biafrans (Gaffey, 2016). Prior to the general election in 2015, the All Progrsesive Congress (APC), now ruling party in Nigeria petitioned the ICC over alleged inciting remarks by the wife of the former president Goodluck Jonathan (Tijani, 2015). In 2018, the current main opposition party, the Peoples Democratic Party (PDP) reported the President, Muhamadu Buhari, "for boasting over violation of fundamental rights of Nigerians during his regime as military Head of State" (Ezigbo, 2018)

Nigerian civil society organizations petitioned the ICC in respect of killings and human rights violations in Rivers State during the general elections of 2015. The Civil Society Network against Corruption (CSNAC) prayed the Court to investigate, arrest and prosecute persons involved in murders, assaults and other acts of violence associated with the elections (Premium Times, 2016). The civil society groups have also referred the perennial problem of corruption and mismanagement of public funds to the Court. The Socio-Economic Right and Accountability Project (SERAP) petitioned the Court over alleged 11 trillion naira electricity scam since the return of democracy in 1999, alleging that it is a crime against humanity (Premium Times, 2017). A human rights crusader and Senior Advocate of Nigeria (SAN), Femi Falana, also petitioned the ICC over alleged mismanagement of funds allocated to the procurement of weapons (Eribake, 2016). By July, 2018, the ICC had confirmed receiving 131 petitions from Nigeria on killings and general insecurity (Abdullahi, 2018) and that under Article 15 of the Rome Statute, individuals or groups could send such petitions.

Nigerians have no doubt demonstrated an unflinching support and faith in the Court. Thus rather than see the ICC as a 'white man's court or an instrument of neocolonialism, Nigerians from all shades of opinion have come to appreciate it as the peoples' court and last hope of the common man, especially in the light of the inadequacies, failings and politicization of the national justice system.

\subsection{Justice for the Victims and Best Interest of Africans}

Holding African political and military leaders accountable for their actions is in the best interest of Africans, especially the millions of victims who are yearning for justice (Shilaho, 2018). Whenever, the pursuit of war criminals in Africa is debated, very few remember or mention the victims of such crimes, who are entitled to justice (Garbett, 2017). While it may not be possible to bring such perpetrators to justice before a national tribunal, an international court remains the most viable alternative (Assogbavi, 2017). One can never imagine the prosecution of erstwhile president Omar al Bashir in a Sudanese Court for war crimes and crimes against humanity.

Critics of ICC always ignore victims' rights (Balasco, 2013:58). By keeping their interests, concerns and rights among its primary objectives, the ICC is poised to do justice with a human face and help in the healing process and recovery, which is and ought to be its ultimate goal (Garbett, 2017). Uhuru Kenyatta and William Ruto are the first serving government leaders to appear before the ICC. Their prosecution represents victory for the ICC and victims of the crimes. So it is critical to take into consideration the interest of the victims who are desirous of justice, as there can be no true peace, reconciliation and stability without justice to them.

\subsection{No Credible National Investigations or Prosecutions}

Credible national investigations and prosecutions of perpetrators of war crimes and crimes against humanity are virtually non-existent in Africa. In post war Liberia, Sierra Leone, Sudan, Uganda, Congo, Mali and other African countries, national trial was non-existent. Some of the countries opted for truth and reconciliation which should not be applicable to serious international crimes. Kimani (2009) describes it as failure of Africa's domestic judicial systems. According to the writer "There would be less need for the ICC to engage in Africa if the continent's governments did a better job of bringing to justice those responsible for atrocities. That should be the ultimate goals of every state" (Kimani, 2009). An attempt by Kofi Anan to get a national trial under way in Kenya to prosecute persons responsible for the 2007 post-election violence failed (Khamis, 2011). The Kenyan authorities were unable or unwilling to prosecute them. It was at that point the ICC took over the case.

\subsection{Are there any Merits in the Indictments?}

It is also important to interrogate further whether there are merits in the indictments, prosecutions and warrants of arrest issued against these Africans by the ICC. Are there any frivolous, vexatious, malicious or fabricated allegations against them? All of them are no doubt meritorious (Kahn, 2009). 
The degree of cruelty, brutality and inhumanity meted out by these political and military leaders to their citizens cannot be ignored or swept under the carpet. As any society that engages in such activities cannot make progress.The major discontent of these leaders rests on the exclusive prosecution of cases in Africa and those cases lacks merit. Thus if the ICC resolves to pursue cases in other parts of the world as it is beginning to do, will the allegation of targeting Africans be shelved and justice allowed to take its course?

\subsection{Investigations Requested or Supported by African States}

The assertion or conclusion that the ICC is unfairly targeting Africans is significantly weak, unmeritorious andnot supported by facts.This is the opinion expressed by supporters of the ICC in Africa. According to them, investigations into African situations have been opened at the request or with the support of African states (Keppler, 2011). Four out of these situations were self-referrals Uganda,DRCongo, CARand Mali.The self-referrals indicate that it is not the Court that is targeting African States. ThoseStates rather asked for the Court's assistance (Assogbavi, 2017). Twosituations - Libya and Sudan were referred by the United Nations Security Council. The referral was supported by African states. The DRCongo, Benin and Tanzania voted in favour of the UN Security Council referral of the Darfur situation to the ICC. In the case of Libya, South Africa, Garbon and Nigeria voted in favour of Security Council referral of the situation to the ICC. Only two situations, Kenya and Cote d'Ivoire, were initiated through the prosecutor's own motions. Kenya had promised to support the Prosecutor's investigation into the crimes proprio motu. Cote d'Ivoire accepted the jurisdiction of the Court and promised to cooperate with it (Assogbavi, 2017).

\section{THE ICC: A GIANT STEP FORWARD}

The birth of the ICC depicted a new era in the international justice system. At the signing ceremony of the Court's Statute the former UN Secretary General, Kofi Annan described the ICC as "a giant step forward in the march towards universal human rights and the rule of law" (Allo, 2018). More than two decades after that optimistic declaration, the world is still very far from achieving universal human rights, justice and the rule of law through the instrumentality of the ICC. Enforcement of human rights has been relegated to Africa. Powerful states and their allies cannot be questioned on issues of human rights violations. The rule of might rather than rule of law prevail and still determine the direction and potency of international law and relations. The United States has threatened to use force against the ICC and recently imposed visa ban on its prosecutors for commencing a probe of war crimes by American personnel in Afghanistan (Wroughton, 2019).

The incursion of the ICC into Africa and its focus on the continent has generated mixed reactions. Allo (2018) opines that the accusations of racism are to some extent embellished and may provide the basis and platform for individuals liable for egregious crimes to invoke "colonialism and racism to avoid responsibility."Allo (2018) blames Eurocentricism and not overt racism for problems of the ICC, noting further that "European imperial values laid the foundation of the ICC and have caused its many problems."A renowned attorney, James Goldston, who served in the ICC prosecutor's office, once remarked that "The fundamental problem is that the Court is operating in a world that is unequal politically and economically" (Zavis and Dixon, 2016).

The situation in which the Court finds itself today - one of weakness - is not new. This has been the attitude of international law from time immemorial: differentstandards for different nations; and a tool in the hands of the major powers. Elsie Keppler (2011) has noted that "It is important to acknowledge that to date, international justice has not been evenly applied, with international courts less likely to prosecute leaders of powerful states, and those they protect, than their counterparts from less powerful states when they are associated with serious crimes. This is a major issue that should be addressed, but in a manner that extends, rather than curtails, accountability, so that victims have recourse to justice, no matter where atrocities are committed." The ICC like other international organizations is a victim of a global struggle for dominance and control by big and powerful states. If this was not the case, United States not being a state party to the Rome Statute,would not enact a law (American ServiceMembers Protection Act of 2002) authorizing use of force to free its personnel from ICC custody (HRW, 2002). In 2002, the US requested other states to sign agreements exempting their citizens from trial by the Court and threatened punitive measures if they did not (Nooruddin and Payton, 2010). It is a ridiculous action for a country which prides itself as the champion of human rights and rule of law. Other big powers like China and Russia have also refused to sign up to the 
treaty and exploit the veto to shield allies. Perennial culprits will try everything to ensure that the Court fails. But it is up to the Court to decide if it wants to succeed or fail. The Court should not be cowed or intimidated by threats or bullying by the big powers.

The support the ICC enjoyed among Africans, especially the political leaders from its start began to wane and diminish because of the way cases from Africa have been handled. The ICC has done well by indicting and prosecuting those persons and should be encouraged. Unarguably, there are flaws in the ICC system. Cassel (1999) describes the Rome Treaty as "a flawed but essential first step." Oriole (2012) observes that "the ICC system is still imperfect and needs to be strengthened and improved."

\section{CONCLuSion}

There is unevenness in the application of international justice. The Court must rise up to its responsibility of holding perpetrators of international crimes accountable. The ICC is global court and must assert its authority and jurisdiction beyond Africa. There are hellish situations around the globe begging for attention. Victims of horrendous crimes are yearning for justice and the Court cannot let them down. It should also intervene in other continents to diminish the prevailing perception of selective justice and double standards.

The Court has commenced preliminary examination of allegations of war crimes and crimes against humanity by American personnel in Afghanistan. Though this is a daunting task and a seemingly impossible one, the Court is enjoined to stand firm and press charges. Crimes committed in the Palestinian territories appear to have been forgotten. If it wants to be seen as a credible organization out to dispense global justice fairly and not as a political tool of vengeance in the hands of big powers, as it is being perceived, the ICC must pursue these cases to their logical conclusion. The world is watching!

\section{REFERENCES}

[1] Abdullahi, D. (2018) "ICC receives petitions on killings in Nigeria" Press TV Available at https://www.presstv.com/> 2018/07/17 last visited 18/4/2019

[2] Adedimeji, A. (2015) "Nigeria Elections, Obama and ICC Warning" all Africa, Daily Independent Available at allafrica.com/stories/2015 last visited 17/5/2019

[3] Alamuddin, A. (2012) "Will Syria go to the ICC?" The Lawyer, 10 December

[4] Aljazeera (2019) "ICC urged to investigate Syria's forced deportations" Available at www.aljazeera.com/news/2019 last visited 17/4/2019

[5] Alleblas, T., Aloyo, E., Dancy, G. and Dutton, Y. (2017) "Is the International Criminal Court biased against Africans?" The Washington Post Available at https://www.washingtopost.com/news last visited $17 / 4 / 2019$

[6] Allo, A.K. (2018) "The ICC's problem is not overt racism, it is Eurocentricism"

[7] ALJAZEERA Available at www.aljazeera.com/indepth/opinion last visited 17/4/2019

[8] Assogbavi, D.Y. (2017) "The ICC or the AU: Who can ensure justice for African victims?" Coalition for the International Criminal Court Available at https://www.coalitionfortheicc.org/news/20 last visited $12 / 5 / 2019$

[9] Ba, O. (2016) "Who is Laurent Gbagbo, and why is he on trial at the ICC? The Washington Post Available at Https://www.washingtonpost.com/news last visited 19/4/2019

[10] Balasco, L.M. (2013) "The International Criminal Court as a Human Security Agent" PRAXIS The Fletcher Journal of Human Security Vol XXVIII

[11] Bangamwabo, F. (2008) "International criminal justice and the protection of human rights in Africa" Available at www.kas.de>5-Bangamwabo 15/4/2019

[12] BBC (2013) "Will Africa pull out of the ICC?" BBC News, 11 October

[13] BBC (2015) "Palestinians formally join International Criminal Court" Available at https://www.bbc.com/news/world middle last visited 17/4/2019

[14] BBC (2015) "South Africa court bid to arrest Sudan's Omar al-Bashir" Available at https://www.bbc.com/news/av/worl-africa last visited 27/4/2019

[15] BBC (2019) "Syria war: Lawyers submit first war crimes against Assad" Available at https://bbc.com/news/world-middle last visited 23/4/2019

[16] Benoliel, D. and Perry, R. (2010) "Israel, Palestine and the ICC" Michigan Journal of International Law Vol. 32, Iss.1 
[17] Besant, A. (2013) “Omar al-Bashir flees Nigeria over fears of arrest on ICC charges" GlobalPost at https://www.pri.org/stories/2013-07-16 last visited 27/4/2019

[18] Bob, Y. J. (2019) "U.S., Israel Press ICC against Full War Crimes Probes” The Jerusalem Post Available at https://m.jpost.com/Arab-Israeli-conflict last visited 23/5/2019

[19] Bowcott, O. (2015) "Sudan President Omar al-Bashir leaves South Africa as court considers arrest" The Guardian Available at https://www.theguardian.com/world/2015 last visited 25/4/2019

[20] Cassel, D. (1999) “The Rome Treaty for an ICC: A Flawed but Essential First Step" VI Brown Journal of World Affairs 41 (winter/spring)

[21] CBS News, (2009) “Sudan Dubs The ICC White Man's Court” Available at https;?www.cbsnews.com > news > sudan last visited 15/5/2019

[22] Eribake, A. (2016) “Arms probe: Falana's petition against Dasuki, Okonjo-Iweala arrives ICC” Vanguard Available at https://www.vaguardngr.com/2016/02 last visited 15/5/2019

[23] Ezigbo, O. (2018) "Nigeria: PDP Petitions ICC, UN over Buhari's Comments on Rights Violations" allAfrica Available at allafrica.com/stories/2018 last visited 15/4/2019

[24] Gaffey, C. (2016) "Biafra: Dutch Lawyers File Complaint against Buhari at The Hague" Newsweek at https://www.newsweek.com/biafr-dutch last visited 15/3/2019

[25] Garbett, C. (2017) "The International Criminal Court and restorative justice: Victims, participation and the process of justice" An International Journal Vol. 5, Issue 2 Available at https://www.tandonline.com/doi/full/10 last visited 12/5/2019

[26] Groenler, M. (2015) "The US, the European Union, and the International Criminal Court: Similar values, different interests?" International Journal of Constitutional Law, Volume 13, Issue 4, October

[27] Higgs, R. (2004) “Has the US Government Committed War Crimes in Afghanistan and Iraq?" Independent Institute Available at www.independent.org last visited 15/3/2019

[28] Holmes, O. (2018) "Palestinian minister delivers Israel 'war crimes' referral to ICC" The Guardian Available at https://www.theguardian.com/world/2018 last visited 17/4/2019

[29] Human Rights watch (2002) “U.S.: 'Hague Invasion Act' Becomes Law" Available at https??www.hrw.org/nes/2002/08/03 last visited 11/5/2019

[30] Human Rights Watch (2011) "Security Council Refers Libya to ICC” Available at https://www.hrw.org > news > 2011/02/27 last visited 18/6/2019

[31] Keppler, E. (2011) "Managing Setbacks for the International Criminal Court in Africa" Journal of African Law Vol. 56 Issue I

[32] Moss, L. (2012) "The UN Security Council and the International Criminal Court - Towards a More principled Relationship” International Policy Analysis Available at https://library.fes.de>iez last visited $14 / 5 / 2019$

[33] Murphy, R. (2013) "Many criticisms of International Criminal Court have validity" The Irish Times Available at ww.irishtimes.com last visited 15/2/2019

[34] Nooruddin, I. and Payton, A.L. (2010) "Dynamic of influence in international politics: The ICC, BIAs, and economic sanctions" Journal of Peace Research Vol. 47, No.6 (November)

[35] Oriole, A. "Revisiting the Interaction between the ICC and National Jurisdictions as a New Gateway to Strengthening the Effectiveness of International Criminal Justice" Revue international de droit penal Vol.83 1-2,

[36] Pless, M. D. (2010) The International Criminal Court that Africa Wants Pretoria, Institute for Peace Studies, Monograph 172, August

[37] Plessis, M.D., Maluwa, T. and O’Reilly, A. (2013) “Africa and the International Criminal Court” Chatham House International Law

[38] Premium Times (2016) “"Coalition petitions ICC over politically-motivated killings in Rivers" Press Release, March 2 Available at https://www.premiumtimesng.com/news last visited 13/5/2019

[39] Punch (2018) "Insecurity: ICC receives 131 petitions from Nigeria" Available at https://punch.com > insecurity-icc-rece last visited 23/5/2019

[40] Premium Times (2017) “ICC considers SERAP's petition on alleged N11 trillion electricity scam” Press Release Available at https://www.premiumtimesng.com>news/mo last visited 13/5/2019

[41] Roth, K. (2014) "Africa Attacks the International Criminal Court" The New York Review Of Books, February 6, Vol. 61, No. 2

[42] Rowe, B.M.P. and Steger, V. "The International Criminal Court: A Case for Conservatives" The American NGO Coalition for the International Court

[43] Sands, P. and Klein, P. (2004) Bowett's Law of International Institutions London: Sweet and Maxwell 
[44] Shilaho, W.K. (2018) "The International Criminal Court and the African Union" AJCR, ACCORD Available at https://ww.accord.org.za>AJCRs last visited 14/5/2019

[45] Smith, W.D. (2009) “The International Criminal Court: The Long Arm of Neocolonialism?” International Affairs Review

[46] Tijani, M. (2015) “EXCLUSIVE: ICC to 'consider' APC's petition against Jonathan's wife over call for stoning" The Cable at https://www.thecable.ng/just-set-investigations last visited 11/5/2019

[47] Tladi, D. (2009 ) "The African Union and the International Criminal Court: The battle for the soul of international law" South Africa Yearbook of International Law Vol. 34

[48] VOA Africa (2010) "Human Rights Groups to Kenya: Arrest al-Bashir" Available at https://www. voanews.com/africa/human last visited 15/6/2019

[49] Werle, G. (2007) “Individual Criminal Responsibility in Article 25 ICC Statute” Journal of International Criminal Justice Volume 5, Issue 4, September

[50] Wroughton, L. (2019) "U.S. imposes visa bans on International Criminal Court - Pompeo" Reuters Available at https://www.reuters.com/article/uk-usa-icc last visited 19/5/2019

[51] Zavis, A. and Dixon, R. (2016) "Only Africans have been tried at the court for worst crimes on Earth" at www.latimes.com last visited 13/4/2019

\section{AUTHOR'S BIOGRAPHY}

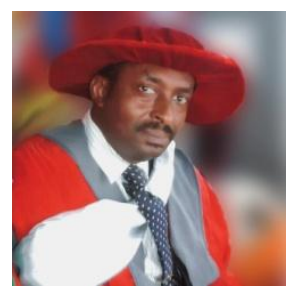

James E. Archibong holds a $\mathrm{PhD}$ in international humanitarian law and teaches human rights and international humanitarian law at the University of Calabar, Cross River State, Nigeria. Former Acting Head, Department of Jurisprudence and International Law, his primary research interest is in human rights and international humanitarian law. He has also published widely and presented papers in these areas.

Citation: James E. Archibong. "The ICC: A Global Court to Fight Impunity or a Court Targeting Africans". International Journal of Humanities Social Sciences and Education (IJHSSE), vol. 6, no.8, 2019, pp. 22-32. doi: http://dx.doi.org/10.20431/2349-0381.0608003.

Copyright: (02019 Authors. This is an open-access article distributed under the terms of the Creative Commons Attribution License, which permits unrestricted use, distribution, and reproduction in any medium, provided the original author and source are credited. 